Article

\title{
Bioprocess Intensification Using Flow Reactors: Stereoselective Oxidation of Achiral 1,3-diols with Immobilized Acetobacter Aceti
}

\author{
Valerio De Vitis ${ }^{1}$, Federica Dall'Oglio ${ }^{2}$, Francesca Tentori ${ }^{3}$, Martina Letizia Contente ${ }^{4}$, \\ Diego Romano ${ }^{1}$, Elisabetta Brenna ${ }^{3} \mathbb{D}$, Lucia Tamborini ${ }^{2, *}$ and Francesco Molinari ${ }^{1, *}$ \\ 1 Department of Food, Environmental and Nutritional Sciences (DeFENS), Università degli Studi di Milano, \\ Via Celoria 2, 20133 Milan, Italy; valerio.devitis@unimi.it (V.D.V.); diego.romano@unimi.it (D.R.) \\ 2 Department of Pharmaceutical Sciences (DISFARM), Università degli Studi di Milano, Via Mangiagalli 25, \\ 20133 Milan, Italy; federica.dalloglio@unimi.it \\ 3 Dipartimento di Chimica, Materiali ed Ingegneria Chimica “Giulio Natta” Politecnico di Milano, Via \\ Mancinelli 7, I-20131 Milan, Italy; francesca.tentori@polimi.it (F.T.); mariaelisabetta.brenna@polimi.it (E.B.) \\ 4 School of Chemistry, University of Nottingham, University Park, Nottingham, NG7 2RD, UK; \\ martina.contente@nottingham.ac.uk \\ * Correspondence: lucia.tamborini@unimi.it (L.T.); francesco.molinari@unimi.it (F.M.); \\ Tel.: +39-02-50319322 (L.T.); +39-02-50319148 (F.M.)
}

Received: 15 January 2019; Accepted: 12 February 2019; Published: 26 February 2019

\begin{abstract}
Enantiomerically enriched 2-hydroxymethylalkanoic acids were prepared by oxidative desymmetrisation of achiral 1,3-diols using immobilized cells of Acetobacter aceti in water at $28^{\circ} \mathrm{C}$. The biotransformations were first performed in batch mode with cells immobilized in dry alginate, furnishing the desired products with high molar conversion and reaction times ranging from 2 to $6 \mathrm{~h}$. The biocatalytic process was intensified using a multiphasic flow reactor, where a segmented gas-liquid flow regime was applied for achieving an efficient $\mathrm{O}_{2}$-liquid transfer; the continuous flow systems allowed for high yields and high biocatalyst productivity.
\end{abstract}

Keywords: oxidation; whole cells; immobilization; biocatalysis; flow reactor; reactor design

\section{Introduction}

Biocatalytic oxidations are attractive reactions, since they often occur with regio- and stereoselectivity, under mild conditions, and utilizing environmentally benign oxidants (i.e., $\mathrm{O}_{2}$ ) [1-3]. Dehydrogenases of acetic acid bacteria are versatile and selective enzymes for alcohol oxidation [4-6]. The production of structurally diverse aldehydes [7], aldoximes [8], lactones [9], and carboxylic acids $[10,11]$ has been achieved using whole cells of acetic acid bacteria, often with high enantioselectivity [12,13]. Stereoselective oxidation of achiral 2-alkyl-1,3-diols has been previously performed in an aqueous solution at room temperature using free whole cells of acetic acid bacteria to afford the corresponding chiral 2-hydroxymethyl alkanoic acids [14,15]. Oxidation of one of the two enantiotopic primary alcohols allowed for desymmetrization of the achiral substrates, furnishing the desired 2-hydroxymethyl alkanoic acids with medium-to-high enantiomeric excesses [15]. Low productivity and side product formation were the main drawbacks of this biotransformation; in fact, formation of the corresponding $\alpha$-methylenic alkanoic acids and $\alpha$-methyl alkanoic acids were observed due to concurrent dehydration, in particular when the substituent in 2-position was ethyl or $n$-propyl [15].

Whole cells can be immobilized for enhancing stability and easy reuse [16]; moreover, immobilization may change substrate/product diffusion, thus affecting reaction rates and altering 
inhibition effects [17]. Additionally, immobilized cells can be used in packed bed flow micro- and meso-reactors, which ensure high surface-to-volume ratios, thus providing high heat and mass transfer rates. Flow packed bed reactors generally ensure that the substrate stream flows at the same velocity through all the reactor volume with no back-mixing $[18,19]$. Flow-based biocatalysis has been successfully applied for improving the performances of different redox biotransformations, such as alcohol oxidation [20], stereoselective carbonyl reduction [21], interconversion of carbonyls and amines using transaminases [22-24], hydroxylation [25,26], and amino acid oxidation [27].

The transfer of gas (air or $\mathrm{O}_{2}$-enriched air) to the aqueous liquid phase is often the factor limiting the efficiency of liquid phase bio-oxidations [28-30]; a way to increase the reaction rate is to facilitate mass transfer by increasing the interfacial area and applying a segmented gas-liquid flow regime [31]. A segmented gas-liquid flow regime (Taylor flow) is characterized by gas bubbles alternating with short liquid slugs with recirculation occurring within segments of the two-phase segmented flow, providing an efficient mass transfer between the gas and liquid phases [18,31,32].

In this work, we have used immobilized cells of Acetobacter aceti MIM 2000/28 for the continuous flow oxidation of 2-alkyl-1,3-diols to chiral 2-hydroxymethyl alkanoic acids. The aim of the work was to intensify this heterogeneous aerobic oxidation using a flow reactor, after the previous observation that oxidation of 2-methyl-1,3-propanediol could be performed [32]. Continuous flow-based oxidation with immobilized cells was carried out under a segmented air-water flow regime. In particular, the reactor consisted of a packed bed reactor with immobilized cells fed with an aqueous solution containing the substrate and a gaseous stream of pressurized air. The three-phase system proved to be highly applicable to the oxidation of different 2-alkyl-1,3-diols with satisfactory selectivity and productivity.

\section{Results}

\subsection{Batch Biotransformations with Immobilized Cells}

Acetobacter aceti MIM 2000/28 was immobilized in dried alginate beads (DALGE), a form of immobilization that proved suitable for preparing packed bed reactors with whole cells used under flow conditions [33] due to the good stability over time and during subsequent cycles of biotransformations. Dried alginate beads showed variable semi-spherical shapes, with diameters ranging from 0.8 to $1.8 \mathrm{~mm}$; when re-hydrated in buffer, DALGE swelled up to spheres with an average diameter of $3.2 \mathrm{~mm}$. 2-Methyl-1,3-propanediol 1a was firstly used as current substrate for optimizing the biotransformation in batch mode. Substrate concentration, buffer $\mathrm{pH}$, and immobilized cells concentration were used as control parameters, and optimization was carried out using a multisimplex approach [34]; conversion and enantiomeric excess of the product were the response variables. Batch biotransformations were carried out at $28^{\circ} \mathrm{C}$ in $10 \mathrm{~mL}$ screw capped tube using $12 \mathrm{mM}$ substrate dissolved in acetate buffer $\left(20 \mathrm{mM} \mathrm{pH} \mathrm{6.0)} \mathrm{with} 40 \mathrm{mg} / \mathrm{mL}\right.$ of alginate beads containing $10 \mathrm{mg}_{\text {dry weight }}$ of cells in a final volume of $2 \mathrm{~mL}$. Optimized batch conditions gave (R)-3-hydroxy-2-methylpropanoic acid 3a with $>97 \%$ molar conversion and ee $=96 \%$ after 120 minutes. Minor amounts of the aldehyde $2 \mathrm{a}(>10 \%)$ were transiently observed during the reaction, before its conversion into 3a (Scheme 1, Figure 1).

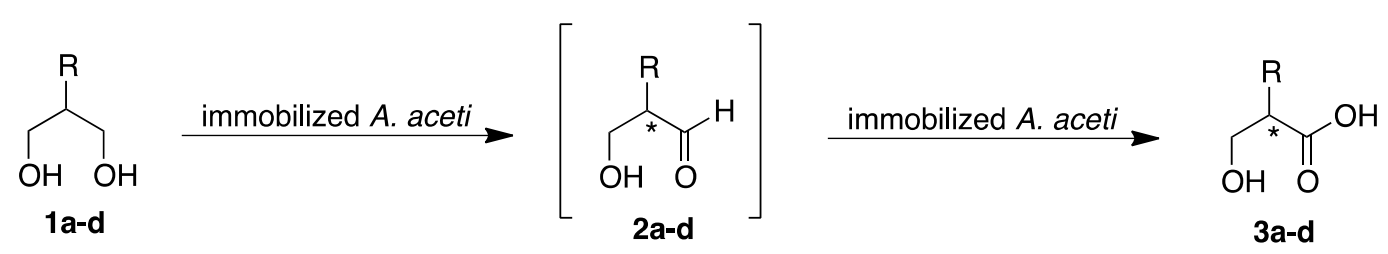

Scheme 1. Oxidation of achiral 2-alkyl-1,3-diols using immobilized Acetobacter aceti. 1a: $\mathrm{R}=\mathrm{Me} ; 1 \mathrm{~b}: \mathrm{R}$ $=\mathrm{Et} ; 1 \mathrm{c}: \mathrm{R}=n-\mathrm{Bu} ; 1 \mathrm{~d}: \mathrm{R}=n$-Pent. 


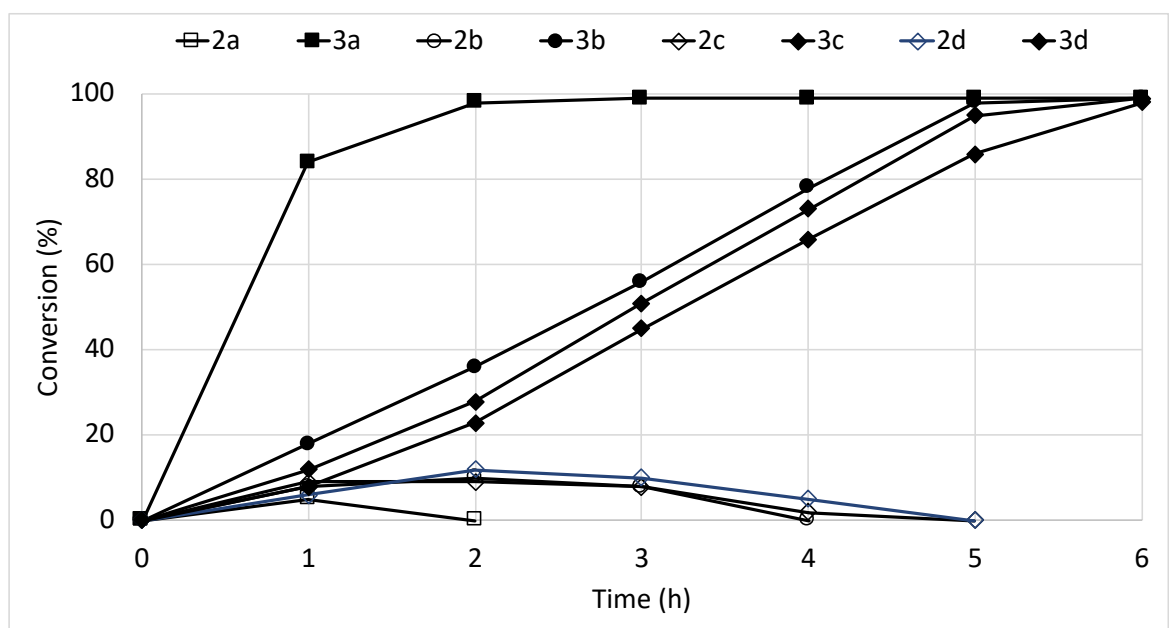

Figure 1. Time-course of the oxidation of achiral 2-substituted 1,3-diols 1a-d with immobilized cells of Acetobacter aceti 2000/28 in conventional shaken flasks (batch mode). Reaction conditions: 0.60 mmol of substrate, $2.0 \mathrm{~g}$ of alginate beads containing $500 \mathrm{mg}_{\text {dry weight }}$ of cells in $50 \mathrm{~mL}$ of acetate buffer $(20 \mathrm{mM}$ $\mathrm{pH} 6.0$ ) at $28^{\circ} \mathrm{C}$.

Considering the good results obtained with compound 1a and the general advantages related to immobilized cells, the biotransformation of achiral 2-alkyl-1,3-diols 1a-d was carried out under the conditions optimized for 1a (Scheme 1).

All the tested substrates gave the desired chiral 2-hydroxymethyl alkanoic acid as the major product, and only small amounts of the intermediate aldehydes were observed during the reaction (Figure 1); enantioselectivity was not affected by immobilization and resulted in the same with free cells [15]. Reaction rates showed a strong dependence on the steric hindrance at the C2 position. Interestingly, dried immobilized cells were much more selective than free cells [15], since the by-products (e.g., $\alpha$-methylenic alkanoic and $\alpha$-methyl alkanoic acids) detected in the biotransformation with free whole cells were not observed.

The stability of the immobilized cells was investigated by re-using the beads in successive reactions (Figure 2). The operational stability was quite limited, since more than $50 \%$ of the original activity was lost after three cycles of reaction.

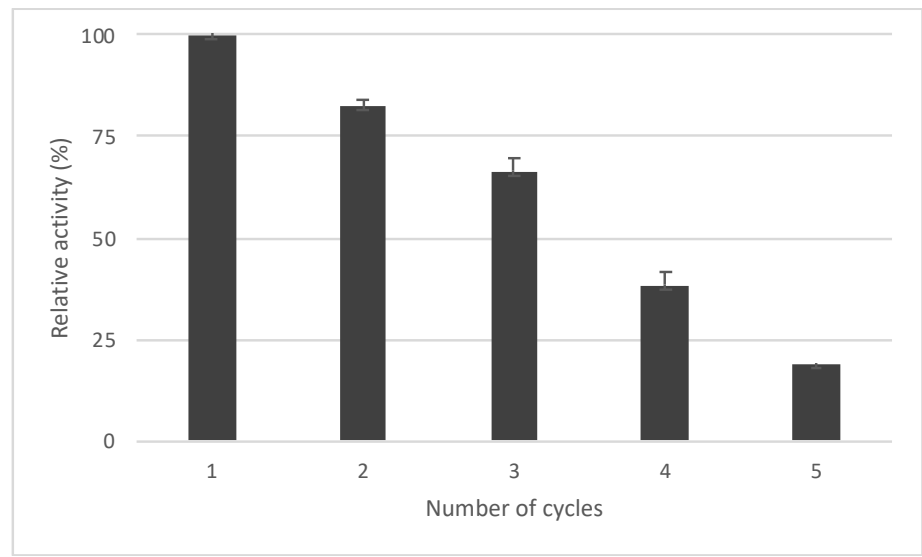

Figure 2. Re-usability of immobilized Acetobacter aceti MIM 2000/28.

\subsection{Oxidation in Flow Reactors}

A packed bed reactor was prepared by filling a glass column (i.d. $15 \mathrm{~mm}$ ) with Acetobacter aceti MIM 2000/28 immobilized in dry alginate beads ( $400 \mathrm{mg}$ containing $100 \mathrm{mg}_{\text {dry weight }}$ of cells) and flowing acetate buffer solution $(20 \mathrm{mM}, \mathrm{pH} 6.0)$ through the column for one hour (flow rate: 
$400 \mu \mathrm{L} / \mathrm{min}$ ). The alginate beads swelled until their volume was triplicated, reaching a final volume of $5.1 \mathrm{~mL}$ [32]. A first set of experiments was carried out by simply feeding the packed bed reactor with 1a (12 $\mathrm{mM}$ in acetate buffer) at different flow rates: no trace of biotransformation was found, no matter the flow rate employed. This failure was ascribed to lack of available oxygen in the flow stream, since molecular oxygen takes part in the regeneration of cofactors involved in the microbial oxidation [5]. In order to guarantee a suitable oxygen supply in the aqueous phase, a segmented gas-liquid flow was applied [31]: the gas phase (pressurized air controlled by an air-flow meter) and the liquid phase (buffer solution containing the substrate driven by a HPLC pump) merged in a T-junction, thus generating air-liquid segments in the flow stream entering the reactor (Figure 3).

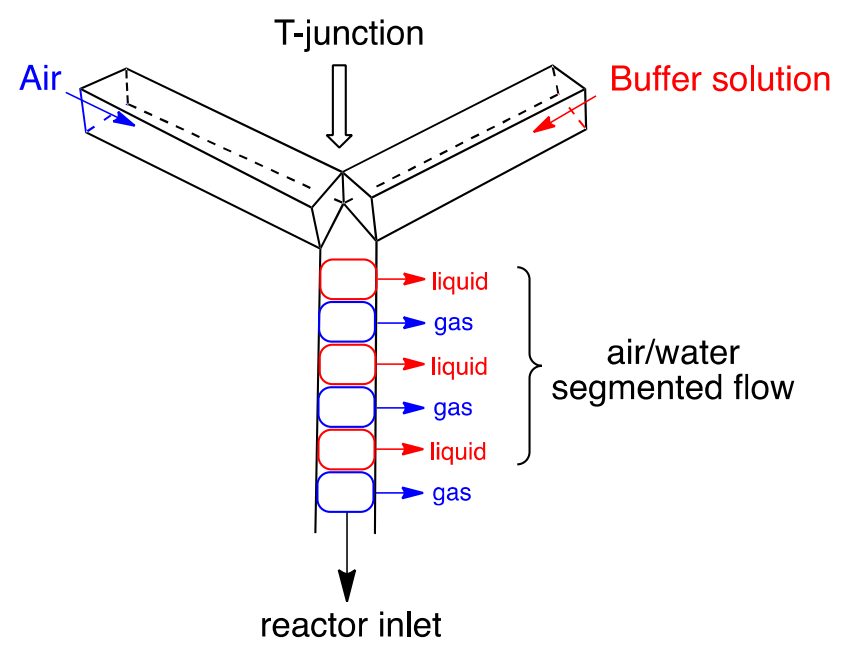

Figure 3. Schematic diagram of the experimental setup used to originate the segmented gas-liquid flow.

Table 1 shows the specific reaction rates and the conversions obtained by varying substrate concentration and flow rate of the liquid phase. The specific reaction rate $\left(r_{\mathrm{f}}\right)$ of the continuous-flow system was calculated from the concentration of the formed product ([P] expressed as $\mu \mathrm{mol} \mathrm{mL}^{-1}$ ), the flow rate of the liquid phase (f expressed as $\mathrm{mL} / \mathrm{min}$ ), and the mass of the biocatalyst expressed as

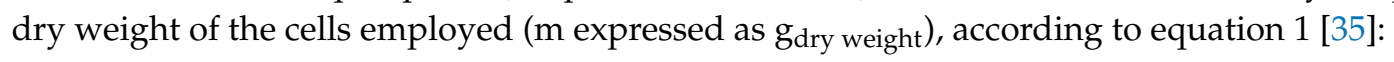

$$
r_{\mathrm{f}}=[\mathrm{P}] \cdot \mathrm{f} / \mathrm{m}\left(\mu \mathrm{mol} \mathrm{min}^{-1} \mathrm{~g}^{-1}\right)
$$

Table 1. Continuous flow enantioselective oxidation of 1a with immobilized Acetobacter aceti MIM $2000 / 28$.

\begin{tabular}{|c|c|c|c|c|}
\hline Entry & Substrate [mM] & Flow Rate ${ }^{a}\left(\mu \mathrm{L} \min ^{-1}\right)$ & $r_{f}\left(\mu \mathrm{mol} \mathrm{min}^{-1} \mathrm{~g}_{\text {dry cells }}{ }^{-1}\right)$ & $c^{b}(\%)$ \\
\hline 1 & 12 & 15 & 1.80 & $>97$ \\
\hline 2 & 12 & 30 & 3.60 & $>97$ \\
\hline 3 & 12 & 60 & 6.12 & 85 \\
\hline 4 & 24 & 15 & 3.60 & $>97$ \\
\hline 5 & 24 & 30 & 7.20 & $>97$ \\
\hline 6 & 24 & 60 & 7.78 & 54 \\
\hline 7 & 36 & 15 & 4.86 & 90 \\
\hline 8 & 36 & 30 & 8.21 & 76 \\
\hline 9 & 36 & 60 & 11.88 & 55 \\
\hline
\end{tabular}

${ }^{a}$ Flow rate of the liquid phase. ${ }^{b}$ Conversions determined by HPLC.

The highest rate was achieved with a liquid flow rate of $60 \mu \mathrm{L} \mathrm{min}{ }^{-1}$ with an inflowing solution containing $36 \mathrm{mM}$ of substrate (entry 9, Table 1), but the most favourable compromise between rate and complete conversion was achieved at lower liquid flow rate $\left(30 \mu \mathrm{L} \mathrm{min}{ }^{-1}\right.$; entry 5, Table 1). 
Under these conditions (table 1, entry 5), to evaluate the stability of the bioreactor, the continuous flow reaction was then performed over $24 \mathrm{~h}$. As depicted in Figure 4, the biocatalyst showed excellent performance in terms of conversion for the first $12 \mathrm{~h}$; then, a slight decrease of the initial activity was observed, obtaining $82 \%$ of conversion after $24 \mathrm{~h}$ (Figure 4). No release of enzymatic activity was observed in the outlet flow during the continuous operation.

Table 2. Continuous enantioselective oxidation of achiral 2-substituted 1,3-diols 1a-d (24 mM) with immobilized Acetobacter aceti MIM 2000/28 in continuous flow. Liquid flow stream: $30 \mu \mathrm{L} \mathrm{min}^{-1}$.

\begin{tabular}{ccccc}
\hline Entry & Substrate & c (\%) & ee (\%) & $r_{f}\left(\mu \mathbf{m o l ~} \mathbf{~ m i n}^{-\mathbf{1}} \mathbf{g}_{\text {dry cells }}{ }^{-1}\right)$ \\
\hline 1 & $1 \mathrm{a}$ & $>97$ & $96(R)$ & 7.20 \\
2 & $1 \mathrm{~b}$ & $>97$ & $59(R)$ & 7.20 \\
3 & $1 \mathrm{c}$ & $>97$ & $80(S)$ & 7.20 \\
4 & $1 \mathrm{~d}$ & $>97$ & $88(S)$ & 7.20 \\
\hline
\end{tabular}

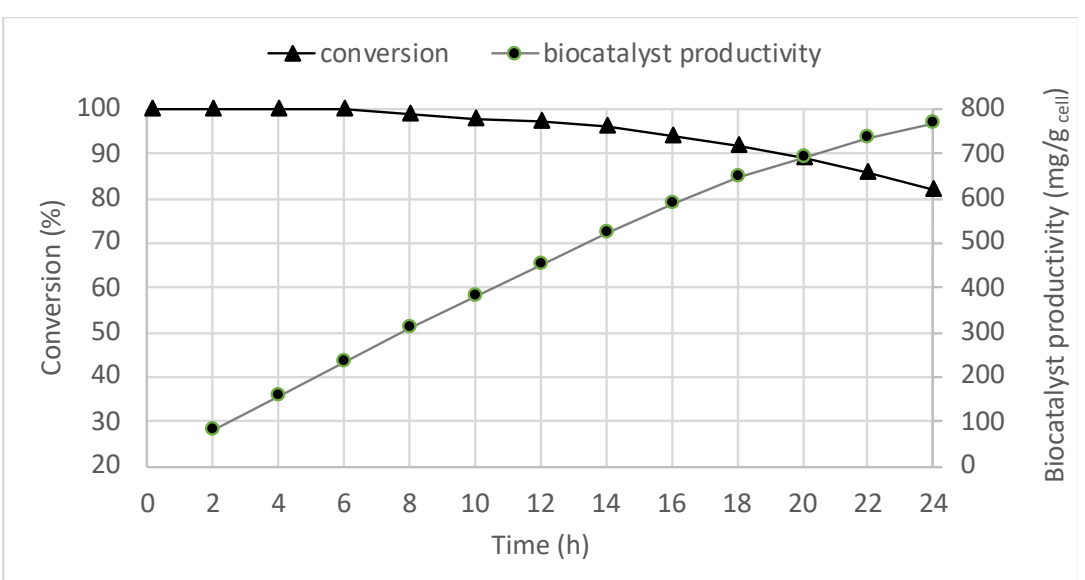

Figure 4. Continuous enantioselective oxidation of 1a with immobilized Acetobacter aceti MIM 2000/28 in flow under the conditions reported in Table 2, entry 5. Biocatalyst productivity is defined as the overall amount of product $(\mathrm{mg})$ formed per dry weight of biocatalyst.

An in-line purification step was applied, consisting of an ion exchange Ambersep $900 \mathrm{OH}^{-}$ resin, able to quantitatively catch the acid contained in the outflowing stream [33]. Acid 3a was then recovered as chemically pure product $(>99.8 \%$ pure by NMR, ee $96 \%$ ) after elution from the resin with a $1 \mathrm{~N} \mathrm{HCl}$ solution. A schematic representation of the main components of the flow reactor configuration is represented in Scheme 2.

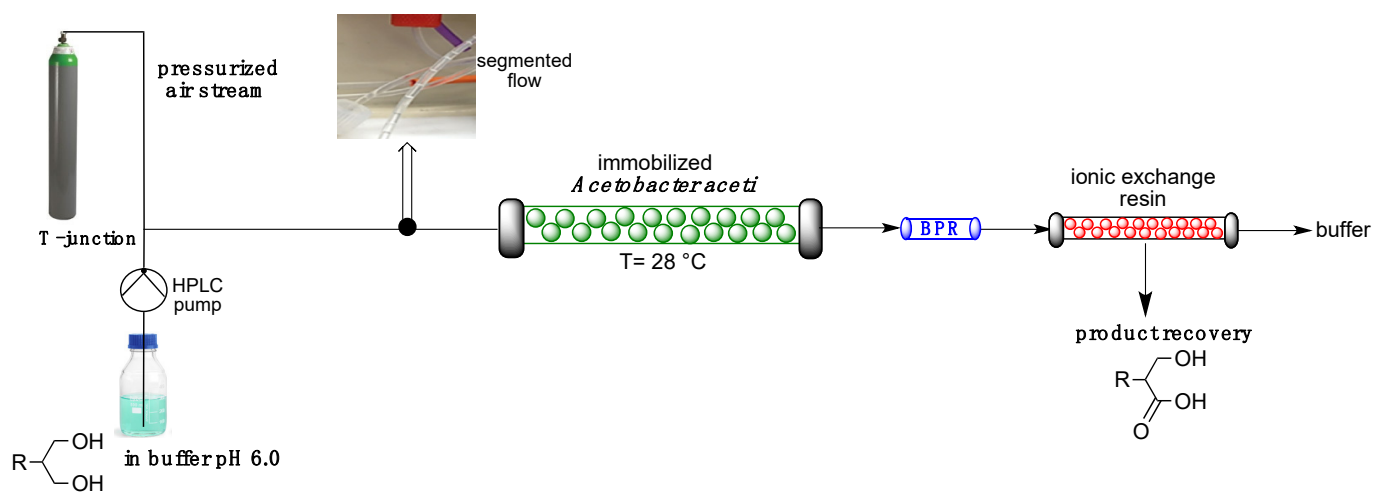

Scheme 2. Outline of the flow reactor and recovery system. 
Finally, the conditions optimized for the oxidation of 1a were employed for the continuous oxidation of substrates $1 \mathrm{~b}-\mathrm{d}$ (Table 2). The continuous flow biotransformation of diols $1 \mathrm{~b}-\mathrm{d}$ occurred with high rates and total conversion of the substrate into the desired chiral hydroxy acid under the optimized conditions previously used for the oxidation of 1a (24 mM substrate concentration; liquid flow stream $30 \mu \mathrm{L} \mathrm{min}^{-1}$ ), proving that the experimental set-up optimized in this work could be generally applied.

\section{Discussion}

Desymmetrisation of achiral 1,3-diols with Acetobacter aceti has been previously shown to be an effective procedure for the preparation of enantiomerically enriched hydroxymethyl alkanoic acids [15]. Batch reaction with free cells of Acetobacter aceti was not selective, since formation of the corresponding $\alpha$-methylenic alkanoic and $\alpha$-methyl alkanoic acids was observed [15]. Immobilization of the whole cells using dry alginate beads, beyond the advantages of easier work up and potential catalyst reusability, was found to be an excellent tool for improving the selectivity of the reactions with respect to the use of cell free systems. In fact, chiral 2-hydroxymethyl alkanoic acids were obtained as the only final products. The lack of side reactions can be justified considering that cell entrapment alters substrate and product diffusion through the solid support, as already observed in literature using similar systems [7,17].

As further improvement, the oxidation of diols 1a-d was tested under continuous-flow conditions, exploiting the application of alginate beads in a packed bed reactor. A segmented air-water flow regime (which ensured high mass transfer between the gaseous and the liquid phase) was successfully applied to all the tested substrates. A comparison between the operational stability between batch and flow reactors showed that re-utilization under batch conditions was very limited, whereas the continuous reaction could be performed for $24 \mathrm{~h}$ under flow conditions, with increased overall productivity. However, the oxidative activity showed by immobilized cells decreased in any case during semi-continuous or continuous operations; this could be due to partial damage of the immobilized system or to impairment of the redox system involved in the stereoselective oxidation. In fact, membrane-bound dehydrogenases of acetic acid bacteria involved in the oxidation of alcohols utilize different types of cofactors $\left(\mathrm{NAD}^{+}, \mathrm{NADP}^{+}, \mathrm{PQQ}\right)$, which may be lost if cells are damaged by mechanical stress (mostly occurring in agitated flasks) or shear stress (mostly occurring in flow reactors), although, in our case, no apparent leaking of enzymatic activity was observed during the continuous flow operation. One important issue of the described flow-based biocatalytic process concerns the overall intensification with reduction of the reactor size, while improving yields and biocatalyst productivity with respect to the batch process. Finally, the flow system could be easily used for the oxidation of different substrates with remarkable acceleration compared to the batch mode.

\section{Materials and Methods}

\subsection{General}

All reagents and solvents were purchased from Sigma-Aldrich (Milano, Italy). The synthesis of 2-alkyl-1,3-diols $1 \mathrm{~b}-\mathrm{d}$ was carried out according to the procedure already described in ref. 15 . The full characterization data of diols $1 \mathrm{~b}-\mathrm{d}$ and of the corresponding products of $A$. aceti-mediated oxidation have been already reported [15]. The conversion values of the bio-oxidation of diols $1 \mathrm{~b}-\mathrm{d}$ were determined by ${ }^{1} \mathrm{H}$ NMR analysis of the crude mixtures. The continuous flow reactions were performed using a commercial R2C/R4 flow reactor (Vapourtec, Bury St. Edmunds, Suffolk, UK) equipped with Omnifit glass columns (15 mm i.d.) and Sierra mass flow controller (Smeri, Milano, Italy). The ${ }^{1} \mathrm{H}$ NMR and ${ }^{13} \mathrm{C}$ NMR spectra were recorded with a Varian Mercury 300 (300 MHz) spectrometer. The molar conversion of the biotransformation was determined by HPLC analysis using a Luna $\mathrm{NH}_{2} 100 \AA$ column $(250 \mathrm{~mm} \times 4.6 \mathrm{~mm}$, particle size $5 \mu \mathrm{m}$, Phenomenex, Aschaffenburg, Germany) and a Biorad refractor index detector (Segrate, Milano, Italy) with an acidic 
aqueous $\mathrm{KH}_{2} \mathrm{PO}_{4}$ buffer $\left(20 \mathrm{mM}\right.$, $\mathrm{pH}$ 2.7) as the mobile phase (flow rate $0.2 \mathrm{~mL} \mathrm{~min}^{-1}$ ). The samples were injected as soon as collected and without further treatment. The enantiomeric excess values were evaluated in the following way: enantiomeric composition of $3 a$ and $3 \mathrm{c}$ was determined by chiral gas chromatographic analysis of the corresponding methyl ester obtained after treatment with $\mathrm{CH}_{2} \mathrm{~N}_{2}$. Analysis of methyl-3-hydroxy-2-methylpropionate (column and conditions: diameter $0.25 \mathrm{~mm}$, length $25 \mathrm{~m}$, DMePeBeta-CDX-PS086, MEGA, Legnano, Italy; isothermal at $\left.80^{\circ} \mathrm{C}\right): \mathrm{t}_{\mathrm{r}} R$-enantiomer $=6.5 \mathrm{~min} ; \mathrm{t}_{\mathrm{r}} S$-enantiomer $=7.2 \mathrm{~min}$. Analysis of methyl-2-(hydroxymethyl)hexanoate (column and conditions: diameter $0.25 \mathrm{~mm}$, length $25 \mathrm{~m}$, DAcTBSil-BetaCDX, MEGA, Legnano, Italy; T gradient:

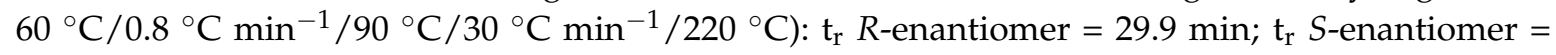
$30.6 \mathrm{~min}$. Enantiomeric composition of $3 \mathrm{~b}$ and $3 \mathrm{~d}$ was determined by chiral HPLC analysis after derivatization first with $\mathrm{CH}_{2} \mathrm{~N}_{2}$, then with 3,5-dinitrobenzoyl chloride (column and conditions: Chiralcel OD, $n$-hexane $/ i$-PrOH 9:1, $0.6 \mathrm{~mL} / \mathrm{min}, 25^{\circ} \mathrm{C}$ ). Derivative of $3 b$ : $t_{\mathrm{r}} R$-enantiomer $=51.30 \mathrm{~min}$; $\mathrm{t}_{\mathrm{r}} S$-enantiomer $=61.32 \mathrm{~min}$. Derivative of $3 \mathrm{~d}$ : $\mathrm{t}_{\mathrm{r}} R$-enantiomer $=45.1 \mathrm{~min}, \mathrm{t}_{\mathrm{r}} S$-enantiomer $=57.0 \mathrm{~min}$.

\subsection{Strain Preparation}

Acetobacter aceti MIM 2000/28 was maintained on solid medium [glucose $\left(50 \mathrm{~g} \mathrm{~L}^{-1}\right)$, yeast extract $\left(10 \mathrm{~g} \mathrm{~L}^{-1}\right), \mathrm{CaCO}_{3}\left(30 \mathrm{~g} \mathrm{~L}^{-1}\right)$, agar $\left(15 \mathrm{~g} \mathrm{~L}^{-1}\right), \mathrm{pH} 6.3$ ] at $28^{\circ} \mathrm{C}$. Liquid cultures were inoculated into $100 \mathrm{~mL}$ Erlenmeyer baffled flask containing $20 \mathrm{~mL}$ of GLY medium [yeast extract $\left(10 \mathrm{~g} \mathrm{~L}^{-1}\right)$ and glycerol $\left(25 \mathrm{~g} \mathrm{~L}^{-1}\right), \mathrm{pH}$ ] and incubated under orbital shaking $(150 \mathrm{rpm})$ at $28{ }^{\circ} \mathrm{C}$, grown for $24 \mathrm{~h}$; this liquid culture was used as inoculum for liquid cultures of $200 \mathrm{~mL}$ (GLY medium in a $1 \mathrm{~L}$ Erlenmeyer baffled flask) incubated under orbital shaking $(150 \mathrm{rpm})$ at $28^{\circ} \mathrm{C}$ grown for $24 \mathrm{~h}$. Cells were harvested by centrifugation and suspended in sodium acetate buffer $(20 \mathrm{~mm}, \mathrm{pH} 6.0)$.

\subsection{Preparation of Dry Alginate Beads}

Gel beads were obtained by mixing a solution of sodium alginate $(4 \% w / v)$ in distilled water; $200 \mathrm{~mL}$ of this solution was then gently mixed with $200 \mathrm{~mL}$ of a suspension of $A$. aceti cells $\left(40 \mathrm{OD}_{60 \mathrm{~nm}}\right)$ in sodium acetate buffer $(20 \mathrm{~mm}, \mathrm{pH} 6.0)$. The resulting suspension was pumped using a peristaltic pump (MasterFlex, Cole Parmer, USA) with a constant flow rate of $3.0 \mathrm{~mL} \mathrm{~min}^{-1}$ into $200 \mathrm{~mL}$ of a $\mathrm{CaCl}_{2}$ solution $(0.2 \mathrm{M})$ kept under gentle magnetic stirring. At the end of the addition, calcium alginate beads were kept under magnetic stirring for $20 \mathrm{~min}$, then filtered, washed with deionized water, and dried at $25^{\circ} \mathrm{C}$ for $16 \mathrm{~h}$. Dried alginate beads showed very variable sizes (with diameters ranging from 0.8 to $1.8 \mathrm{~mm}$ ) with semi-spherical shapes, whereas re-hydrated alginate beads showed spherical structures with diameters of $3.2 \pm 0.3 \mathrm{~mm}$. The size of the beads was measured by placing the beads on a graph paper and amplifying the image captured with a digital camera.

\subsection{General Batch Procedure for the Preparation of Mono-Carboxylic Acids (3a-d)}

A $12 \mathrm{mM}$ solution of compounds 1a-d was prepared in acetate buffer $\mathrm{pH}$ 6.0. A concentration of $40 \mathrm{mg} / \mathrm{mL}$ of alginates was used (containing $10 \mathrm{mg}$ of whole cells). The reaction was maintained at $28^{\circ} \mathrm{C}$. The reaction was followed by HPLC. After 120 minutes, the mixture was acidified until $\mathrm{pH} 2$ and it was extracted with ethyl acetate (10-12 times). The organic phase was dried on $\mathrm{Na}_{2} \mathrm{SO}_{4}$ and the solvent was evaporated under reduced pressure. Enantiomeric excesses were detected by chiral GC after derivatization with diazomethane or by chiral HPLC.

A. aceti MIM 2000/28 entrapped in alginate beads was re-used in successive oxidation of 1a for evaluating the operational stability. After $2 \mathrm{~h}$, the reaction mixture was filtered, and the beads were washed twice with buffer and re-suspended in the reaction mixture (acetate buffer at $\mathrm{pH} 6.0$ containing $12 \mathrm{mM}$ of $1 \mathrm{a})$.

\subsection{General Flow Procedure for the Preparation of Mono-Carboxylic Acids (3a-d)}

Dry alginate beads (400 mg, containing $100 \mathrm{mg}_{\text {dry weight }}$ of cells of $A$. aceti) were packed into a glass column (i.d. $15 \mathrm{~mm})$, and acetate buffer $(20 \mathrm{~mm}, \mathrm{pH}$ 6.0) was flowed through the column at a 
constant flow rate of $400 \mu \mathrm{L} \mathrm{min}{ }^{-1}$ for $60 \mathrm{~min}$, reaching a final volume of $5.1 \mathrm{~mL}$. Air was delivered at $17 \mathrm{psi}$, and its flow was measured and controlled thanks to a mass flow controller device $(6 \mathrm{~mL}$ $\left.\min ^{-1}\right)$. A buffer solution of $1 \mathrm{a}-\mathrm{d}(24 \mathrm{mM}$ in acetate buffer $20 \mathrm{mM} \mathrm{pH} 6.0)$ was pumped at $30 \mu \mathrm{L}$ $\mathrm{min}^{-1}$, joining the airflow at the T-junction, before entering the column in which the oxidation took place, with a residence time of about $10 \mathrm{~min}$. A BPR (5 psi) was applied. The exiting flow stream was directed into a column filled with Ambersep $900 \mathrm{OH}$ resin $(2 \mathrm{~g})$, and, after washing the column with water $\left(20 \mathrm{~mL}, 0.5 \mathrm{~mL} \mathrm{~min}^{-1}\right)$, the trapped acid was released by flowing aqueous $\mathrm{HCl}(1 \mathrm{~N}, 5 \mathrm{~mL})$. Reactions were followed by HPLC, and ee were calculated with chiral GC after derivatization with diazomethane or with chiral HPLC.

Author Contributions: Conceptualization, F.M., L.T., and E.B.; methodology, V.D.V., F.D.A., M.L.C., and F.T.; validation, D.R. and L.T.; formal analysis, F.T., M.L.C., V.D.V., and F.D.A.; investigation, D.R., V.D.V., and M.L.C.; resources, D.R. and E.B.; data curation, F.M., L.T., and E.B.; writing—original draft preparation, F.M. and L.T.; writing-review and editing, all the authors; supervision, F.M., L.T., E.B., and D.R.; project administration, F.M., L.T., and E.B.

Funding: Authors thank Cariplo Foundation (Project 2014-0568: INBOX, Innovative Biocatalytic Oxidations) for funding.

Conflicts of Interest: The authors declare no conflict of interest.

\section{References}

1. Hollmann, F.; Arends, I.W.C.E.; Buehler, K.; Schallmey, A.; Bühler, B. Enzyme-mediated oxidations for the chemist. Green Chem. 2011, 13, 226-265. [CrossRef]

2. Molinari, F. Oxidations with isolated and cell-bound dehydrogenases and oxidases. Curr. Org. Chem. 2006, 10, 1247-1263. [CrossRef]

3. Gamenara, D.; Seoane, G.A.; Saenz-Mendez, P.; Dominguez de Maria, P. Redox Biocatalysis; John Wiley \& Sons: Hoboken, NJ, USA, 2012.

4. Saichana, N.; Matsushita, K.; Adachi, O.; Frébort, I.; Frebortova, J. Acetic acid bacteria: A group of bacteria with versatile biotechnological applications Biotechnol. Adv. 2015, 33, 1260-1271. [CrossRef] [PubMed]

5. Yakushi, T.; Matsushita, K. Alcohol dehydrogenase of acetic acid bacteria: Structure, mode of action, and applications in biotechnology. Appl. Microbiol. Biotechnol. 2010, 86, 1257-1265. [CrossRef] [PubMed]

6. Romano, D.; Villa, R.; Molinari, F. Preparative biotransformations: Oxidation of alcohols. ChemCatChem 2012, 4, 739-749. [CrossRef]

7. Gandolfi, R.; Cavenago, K.; Gualandris, R.; Sinisterra Gago, J.V.; Molinari, F. Production of 2-phenylacetic acid and phenylacetaldehyde by oxidation of 2-phenylethanol with free immobilized cells of Acetobacter aceti. Process Biochem. 2004, 39, 747-751. [CrossRef]

8. Zambelli, P.; Pinto, S.; Romano, D.; Crotti, E.; Conti, P.; Tamborini, L.; Villa, R.; Molinari, F. One-pot chemoenzymatic synthesis of aldoximes from primary alcohols in water. Green Chem. 2012, 14, $2158-2161$. [CrossRef]

9. Romano, D.; Contente, M.; Granato, T.; Remelli, W.; Zambelli, P.; Molinari, F. Biocatalytic oxidation of 1,4-diols and $\gamma$-lactols into $\gamma$-lactones: Application to chemoenzymatic synthesis of drospirenone. Monatsh. Chem. 2013, 144, 735-737. [CrossRef]

10. Svitel, J.; Sturdik, E. n-Propanol conversion to propionic acid by Gluconobacter oxydans. Enzyme Microb. Technol. 1995, 17, 546-550. [CrossRef]

11. Habe, H.; Shimada, T.; Yakushi, T.; Hattori, H.; Ano, Y.; Fukuoka, T.; Kitamoto, D.; Itagaki, M.; Watanabe, K.; Yanagishita, H.; et al. Biotransformation of glycerol to D-glyceric acid by Acetobacter tropicalis. Appl. Environ. Microbiol. 2009, 81, 1033-1039. [CrossRef] [PubMed]

12. Romano, A.; Gandolfi, R.; Nitti, P.; Rollini, M.; Molinari, F. Acetic acid bacteria as enantioselective biocatalysts. J. Mol. Catal. B 2002, 17, 235-240. [CrossRef]

13. Keliang, G.; Dongzhi, W. Asymmetric oxidation by Gluconobacter oxydans. Appl. Microbiol. Biotechnol. 2006, 70, 135-139. [CrossRef] [PubMed]

14. Molinari, F.; Gandolfi, R.; Villa, R.; Urban, E.; Kiener, A. Enantioselective oxidation of prochiral 2-methyl-1,3-propandiol by Acetobacter pasteurianus. Tetrahedron Asymmetry 2003, 14, 2041-2043. [CrossRef] 
15. Brenna, E.; Cannavale, F.; Crotti, M.; De Vitis, V.; Gatti, F.G.; Migliazza, G.; Molinari, F.; Parmeggiani, F.; Romano, D.; Santangelo, S. Synthesis of enantiomerically enriched 2-hydroxymethylalkanoic acids by oxidative desymmetrisation of achiral 1,3-diols mediated by Acetobacter aceti. ChemCatChem 2016, 8, 3796-3803. [CrossRef]

16. Polakovic, M.; Svitel, J.; Bucko, M.; Filip, J.; Nedela, V.; Ansorge-Schumacher, M.B.; Gemeiner, P. Progress in biocatalysis with immobilized viable whole cells: Systems development, reaction engineering and applications. Biotechnol. Lett. 2017, 39, 667-683. [CrossRef] [PubMed]

17. Mignot, L.; Junter, G.A. Diffusion in immobilized-cell agar layers: Influence of microbial burden and cell morphology on the diffusion coefficients of l-malic acid and glucose. Appl. Microbiol. Biotechnol. 1990, 32, 418-423. [CrossRef]

18. Bolivar, J.M.; Wiesbauer, J.; Nidetzky, B. Biotransformations in microstructured reactors: More than flowing with the stream? Trends Biotechnol. 2011, 29, 333-342. [CrossRef] [PubMed]

19. Tamborini, L.; Fernandes, P.; Paradisi, F.; Molinari, F. Flow bioreactors as complementary tools for biocatalytic process intensification. Trends Biotechnol. 2018, 36, 73-88. [CrossRef] [PubMed]

20. Šalic, A.; Zelic, B. ADH-catalysed hexanol oxidation with fully integrated NADH regeneration performed in microreactors connected in series. RSC Adv. 2014, 4, 41714-41721. [CrossRef]

21. Dall'Oglio, F.; Contente, M.L.; Conti, P.; Molinari, F.; Monfredi, D.; Pinto, A.; Romano, D.; Ubiali, D.; Tamborini, L.; Serra, I. Flow-based stereoselective reduction of ketones using an immobilized ketoreductase/glucose dehydrogenase mixed bed system. Catal. Commun. 2017, 93, 29-32. [CrossRef]

22. Andrade, L.H.; Kroutil, W.; Jamison, T.F. Continuous flow synthesis of chiral amines in organic solvents: Immobilization of E. coli cells containing both $\omega$-transaminase and PLP. Org. Lett. 2014, 16, $6092-6095$. [CrossRef] [PubMed]

23. Planchestainer, M.; Contente, M.L.; Cassidy, J.; Molinari, F.; Tamborini, L.; Paradisi, F. Continuous flow biocatalysis: Production and in-line purification of amines by immobilised transaminase from Halomonas elongata. Green Chem. 2017, 19, 372-376. [CrossRef]

24. Contente, M.L.; Dall'Oglio, F.; Tamborini, L.; Molinari, F.; Paradisi, F. Highly efficient oxidation of amines to aldehydes with flow-based biocatalysis. Chem CatChem 2017, 9, 3843-3848. [CrossRef]

25. Tomaszewski, B.; Lloyd, R.C.; Warr, A.J.; Buehler, K.; Schmid, A. Regioselective biocatalytic aromatic hydroxylation in a gas-liquid multiphase tube-in-tube reactor. Chem CatChem 2014, 6, 2567-2576. [CrossRef]

26. Willrodt, C.; Halan, B.; Karthaus, L.; Rehdorf, J.; Julsing, M.K.; Buehler, K.; Schmid, A. Continuous multistep synthesis of perillic acid from limonene by catalytic biofilms under segmented flow. Biotechnol. Bioeng. 2017, 114, 281-290. [CrossRef] [PubMed]

27. Bolivar, J.M.; Tribulato, M.A.; Petrasek, Z.; Nidetzky, B. Let the substrate flow, not the enzyme: Practical immobilization of D-amino acid oxidase in a glass microreactor for effective biocatalytic conversions. Biotechnol. Bioeng. 2016, 113, 2342-2349. [CrossRef] [PubMed]

28. Gemoets, H.P.L.; Su, Y.; Shang, M.; Hessel, V.; Luque, R.; Noel, T. Liquid phase oxidation chemistry in continuous- flow microreactors. Chem. Soc. Rev. 2016, 45, 83-117. [CrossRef] [PubMed]

29. Contente, M.L.; Guidi, B.; Serra, I.; De Vitis, V.; Romano, D.; Pinto, A.; Lenna, R.; Pinheiro de Souza Oliveira, R.; Molinari, F. Development of a high-yielding bioprocess for 11- $\alpha$ hydroxylation of canrenone under conditions of oxygen-enriched air supply. Steroids 2016, 116, 1-4. [CrossRef] [PubMed]

30. Chapman, M.R.; Cosgrove, S.C.; Turner, N.J.; Kapur, N.; Blacker, A.J. Highly productive oxidative biocatalysis in continuous flow by enhancing the aqueous equilibrium solubility of oxygen. Angew. Chem. Int. Ed. 2010, $49,2182-2184$.

31. Gunther, A.; Jhunjhunwala, M.; Thalmann, M.; Schmidt, M.A.; Jensen, K.F. Micromixing of miscible liquids in segmented gas-liquid flow. Langmuir 2005, 21, 1547-1555. [CrossRef] [PubMed]

32. De Vitis, V.; Dall'Oglio, F.; Pinto, A.; De Micheli, C.; Molinari, F.; Conti, P.; Romano, D.; Tamborini, L. Chemoenzymatic synthesis in flow reactors: A rapid and convenient preparation of Captopril. Chem. Open 2017, 6, 668-673. [CrossRef] [PubMed]

33. Zambelli, P.; Tamborini, L.; Cazzamalli, S.; Pinto, A.; Arioli, S.; Balzaretti, S.; Plou, F.J.; Fernandez-Arrojo, L.; Molinari, F.; Conti, P.; et al. An efficient continuous flow process for the synthesis of a non-conventional mixture of fructooligosaccharides. Food Chem. 2016, 190, 607-613. [CrossRef] [PubMed] 
34. Romano, D.; Gandolfi, R.; Guglielmetti, S.; Molinari, F. Enzymatic hydrolysis of capsaicins for the production of vanillylamine using ECB deacylase from Actinoplanes utahensis. Food Chem. 2011, 124, 1096-1098. [CrossRef]

35. Csajagi, C.; Szatzker, G.; Toke, E.R.; Urge, L.; Darvasa, F.; Poppe, L. Enantiomer selective acylation of racemic alcohols by lipases in continuous-flow bioreactors. Tetrahedron Asymmetry 2008, 19, 237-246. [CrossRef]

(c) 2019 by the authors. Licensee MDPI, Basel, Switzerland. This article is an open access article distributed under the terms and conditions of the Creative Commons Attribution (CC BY) license (http:/ / creativecommons.org/licenses/by/4.0/). 